\title{
The early embryonic development of the satellite organism Pristionchus pacificus: differences and similarities with Caenorhabditis elegans
}

\author{
Sandra VAngestel, Wouter Houthoofd, Wim Bert and Gaetan Borgonie* \\ Nematology section, Department of Biology, Ghent University, K.L. Ledeganckstraat 35, 9000 Ghent, Belgium
}

Received: 10 July 2007; revised: 22 October 2007

Accepted for publication: 22 October 2007

\begin{abstract}
Summary - As a comparative counterpart for the model organism Caenorhabditis elegans, the nematode Pristionchus pacificus was established as a satellite organism to study developmental processes. However, these studies mainly focused on post-embryonic development and little is known about the early embryonic development. Using 4D microscopy we reconstructed the early embryonic cell lineage of 12 individuals of $P$. pacificus. By analysing several parameters of early development, including the division sequence, the spatial arrangement of blastomeres, the cell cycle patterns of the AB lineage and cell-cell contacts in different cell stages of the embryo, it was shown that the early embryonic development is nearly identical to C. elegans. Known cell-cell contacts necessary for induction of blastomere fates in C. elegans are also present in P. pacificus. Thus, the spatio-temporal conditions that would allow possible homologous inductions are present. However, at least one model for blastomere specification seems not to apply to $P$. pacificus since the third division in the AB lineage differs from that of $C$. elegans. Furthermore, naturally occurring variability of early development was demonstrated, which is clearly permitted since there seems to be no influence on further development into an adult worm.
\end{abstract}

Keywords - 4D microscopy, cell lineage, development, embryogenesis, Neodiplogastridae.

In the last 10 years, the nematode Pristionchus pacificus Sommer, Carta, Kim \& Sternberg, 1996 has been established as a satellite organism in evolutionary developmental biology (Eizinger et al., 1999; Sommer, 2000). For an overview of the biology of this nematode see Hong and Sommer (2006). Pristionchus pacificus belongs to the family Neodiplogastridae, a sister taxon of the family Rhabditidae that includes the model organism Caenorhabditis elegans. Comparative studies between $P$. pacificus and $C$. elegans have revealed differences in the regulation of developmental processes such as the development and genetic analysis of sex determination (PiresdaSilva \& Sommer, 2004), vulva development (Sommer \& Sternberg, 1994, 1996; Sigrist \& Sommer, 1999; Sommer, 2005) and gonad formation (Rudel et al., 2005; Sommer, 2005). For instance, cellular and molecular differences in vulva formation include different cellular interactions as well as different genetic interactions required for cell fate specification of vulval cells (see Eizinger $e t$ al., 1999; Sommer, 2000, 2001, 2005). Recently, developmental and molecular studies of $P$. pacificus have been complemented by genomic data comprising the genetic linkage map (Srinivasan et al., 2002), the physical map (Srinivasan et al., 2003), and whole genome sequencing, which is approaching completion. In addition, the ecology and the specific habitat/ecological niche of $P$. pacificus have been studied. Herrmann et al. (2006) showed that Pristionchus species are often associated with scarab beetles and the Colorado potato beetle. To interpret these ecological patterns, a phylogenetic framework of the genus Pristionchus was recently presented (Mayer et al., 2007).

Developmental studies concerning $P$. pacificus have mainly focused on post-embryonic development and a detailed knowledge of the early development is, at best, fragmentary. Dolinski et al. (2001) studied the time of establishment of the germline cell $\mathrm{P}_{4}$ (late $v s$ early), the arrangement of blastomeres in the four-cell stage (linear, partial linear or oblique) and whether $\mathrm{AB}$ and $\mathrm{P}_{1}$ initially develop at the same (synchronous) or different (asynchronous) rates. The results showed that all character states were the same as in C. elegans. Goldstein et al. (1998) examined how asymmetry is established along

\footnotetext{
* Corresponding author, e-mail: Gaetan.Borgonie@ugent.be
} 
the antero-posterior (a-p) axis. Similar to C. elegans, a-p asymmetry is specified by the sperm which directs cytoplasmic rearrangements, segregating critical factors such as $\mathrm{P}$ granules to one side of the embryo.

However, a detailed analysis of the cell lineage has not yet been described. Here, we present the early embryonic development of $P$. pacificus using 4D microscopy to analyse the cell lineage until the 50-cell stage. The first divisions of early embryonic development have been described for a number of nematodes over the entire phylum (Malakhov, 1994; Goldstein et al., 1998; Voronov \& Panchin, 1998; Dolinski et al., 2001; Schierenberg, 2005; Lahl et al., 2006), whilst analyses up to the 50-cell stage are mainly restricted to members of the orders Rhabditida and Plectida (Skiba \& Schierenberg, 1992; Spieler \& Schierenberg, 1995; Lahl et al., 2003; Hasegawa et al., 2004; Laugsch \& Schierenberg, 2004). Complete cell lineages have only been described for C. elegans (Sulston et al., 1983), Pellioditis marina (Houthoofd et al., 2003), Rhabditophanes sp. (Houthoofd et al., 2007) and Halicephalobus gingivalis (Houthoofd \& Borgonie, 2007). However, the variability of the parameters of early embryonic development has not been studied in detail in nematodes. In the present study, 12 individuals of $P$. pacificus were analysed to gain insight into the naturally occurring variation in the division sequence, the spatial arrangement of blastomeres and the cell cycle patterns of the AB lineage. In addition, cell-cell contacts in different cell stages were examined since, in C. elegans, several cell-cell contacts have been described that are essential, through inductions for blastomere fate specification.

\section{Materials and methods}

\section{NeMATOde CUlture}

Pristionchus pacificus (PS312) was obtained from the CGC, University of Minnesota, USA, and was cultured on agar plates with the uracil-requiring strain of E. coli OP50 as a food source. Handling was as described by Brenner (1974).

\section{D MICROSCOPY AND LINEAGE ANALYSIS}

Pristionchus pacificus embryos were isolated by cutting open gravid hermaphrodites with a scalpel in a drop of distilled water. Embryos in the one- or two-cell stage were transferred to a microscopic slide carrying a thin pad of 5\% agar. Embryos were covered with a cover slip and sealed with Vaseline ${ }^{\circledR}$. Recordings were made using a 4D microscope (Hird \& White, 1993). A Hamamatsu Newvicon camera (C2400-07) recorded 30 focal planes through the embryo every $60 \mathrm{~s}$ (with a distance of 1-1.2 $\mu \mathrm{m}$ between two focal planes) and the software Simple PCI 5.3/6.1.0 (Compix Inc, Tualatin, OR, USA) stored the images on disk. The lineage of each recording was constructed using the Simi Biocell software (version 4.0; Simi, Unterschleissheim, Germany) (Schnabel et al., 1997). By clicking with the mouse pointer on the nucleus of the cell in the window displaying the digitised image, the cell positions were marked and stored in a file. When stored in this fashion, the coordinates $(\mathrm{x}, \mathrm{y})$ of each cell at certain time points can simply be read from this file. The $\mathrm{z}$-coordinate, which was stored as a focal plane, was calculated by multiplying this focal plane by the distance between two focal planes.

The cells are named according to Sulston et al. (1983). When a founder cell divides, each daughter cell is named by adding to the name of the mother cell a single lowercase letter representing its position immediately after division relative to its sister cell. For divisions in the antero-posterior direction, the anterior and posterior daughters are indicated, respectively with ' $a$ ' and 'p', dorsoventral divisions are indicated with ' $d$ ' and ' $v$ ', leftright divisions are indicated with ' $\mathrm{l}$ ' and ' $\mathrm{r}$ '.

Embryos were recorded at $20^{\circ} \mathrm{C}(\mathrm{n}=10)$, at $15^{\circ} \mathrm{C}(\mathrm{n}$ $=1)$ and at $25^{\circ} \mathrm{C}(\mathrm{n}=1)$. Some recordings began in the two-cell stage so the time was set to zero at the division of $\mathrm{AB}$. For clarity and to facilitate discussion, we have opted to compare our data with C. elegans in the Results section.

\section{DETERMINATION OF PARAMETERS OF EARLY DEVELOPMENT}

\section{Blastomere arrangement}

To compare the cellular arrangements of different embryos the 3D option was used. This shows a threedimensional view of all cells present at a particular point in time and allows embryos to be rotated. Cell contacts were assessed in the 8-, 12- and 26-cell stage, and were scored as 'present' if the cells had contact in the period that the embryos were in the 8-, 12- or 26-cell stage, even if this contact was subsequently lost.

\section{Division angles}

The cleavage orientation of all AB cells until the 16ABcell stages and their deviation from the antero-posterior (a-p) axis was calculated. The a-p axis was defined by the centres of $\mathrm{P}_{2}$ in the four-cell stage and the $\mathrm{AB}$-derived 
blastomere, which is placed farthest from $\mathrm{P}_{2}$ in the $32 \mathrm{AB}$ cell stage. Both centres defined a vector $\mathrm{p} 1 \mathrm{p} 2$. When a cell divided, approximately $180 \mathrm{~s}$ after the furrow started to ingress, a vector $\mathrm{p} 3 \mathrm{p} 4$ was drawn between the centres of both daughter cells. The cleavage angle $(\theta)$ with respect to the a-p axis was calculated using the following equation:

$$
\mathrm{p} 1 \mathrm{p} 2 \times \mathrm{p} 3 \mathrm{p} 4=\|\mathrm{p} 1 \mathrm{p} 2\|\|\mathrm{p} 3 \mathrm{p} 4\| \cos \theta
$$

To obtain angles between $0^{\circ}$ and $90^{\circ}$, p1 and p2 were sometimes switched, depending on the orientation of the embryo on the slide.

\section{Results}

\section{GENERAL FEATURES OF EARLY EMBRYOGENESIS}

The early embryonic development of $P$. pacificus showed a fixed cleavage pattern, which is typical for studied members within clades 6-12 in the phylogeny according to Holterman et al. (2006). Development started with a series of unequal cleavages during which a larger somatic founder cell and a smaller germline precursor cell were formed. Subsequent divisions resulted in the formation of five somatic founder cells (AB, MS, E, C, D) and one germline precursor $\mathrm{P}_{4}$ (Fig. 1A, B, E, F). The zygote, $\mathrm{P}_{0}$, divided into an anterior somatic cell, $\mathrm{AB}$, and a posterior germline cell, $P_{1}$. First, the $A B$ cell divided in a perpendicular direction. Then the germline cell $\mathrm{P}_{1}$ divided into an anterior somatic cell, EMS, which determined the future ventral side of the embryo, and a posterior germline cell, $\mathrm{P}_{2}$. One $\mathrm{AB}$ cell migrated to the anterior side $(\mathrm{ABa})$ and the other $\mathrm{AB}$ cell migrated to the future dorsal side of the embryo (ABp). These rearrangements resulted in a rhomboidal configuration typical for members of the Rhabditidae family, with the exception of Protorhabditis sp. (Dolinski et al., 2001). The two AB cells divided into four $\mathrm{AB}$ cells in an identical fashion to C. elegans, where the left-right axis was established at this moment and where the left granddaughters of AB lay anteriorly compared to their sister cells. However, since embryos were not followed beyond the 50-cell stage, it is not known if this division also establishes the left-right axis in $P$. pacificus. Following this stage, the EMS cell divided into an anterior founder cell, MS (mainly mesoderm in $C$. elegans), and a posterior founder cell, E (endoderm). After the division of $\mathrm{P}_{2}$ into a somatic cell, $\mathrm{C}$, and a germline precursor cell, $\mathrm{P}_{3}$, and after the division of $4 \mathrm{AB}$, variation in the division sequence within different individuals was found. This is discussed in detail below.
One prominent deviation from the pattern found in $C$. elegans was a temporal separation between the MS and E divisions in all individuals (Fig. 1A, B, E, F). This has also been observed for several members of the Plectidae family (Lahl et al., 2003). Four recordings were made up to $500 \mathrm{~min}$ of development. During this period, $\mathrm{P}_{4}$, which is present in the 15-cell stage, showed no further divisions. This is in contrast to $C$. elegans where $\mathrm{P}_{4}$ divided in the 110 -cell stage (136 min, own data). Since the antibodies generated against the $\mathrm{P}$ granules of $C$. elegans do not cross-react in P. pacificus (Goldstein et al., 1998), immunostaining of the germline precursor(s) could not be performed. However, $\mathrm{P}_{4}$ must divide in a later stage as it was shown that two germline precursors, Z2 and Z3, were present in the four-cell $P$. pacificus gonad primordium at hatching (Félix et al., 1999; Rudel et al., 2005).

The early development of $P$. pacificus was relatively slower in comparison to $C$. elegans. Considering the time until muscle contraction, $P$. pacificus was at least 1.3 times slower than $C$. elegans. Embryogenesis (time until hatching) took $24 \mathrm{~h}$ in $P$. pacificus, compared to $18 \mathrm{~h}$ in C. elegans at $20^{\circ} \mathrm{C}$ (Félix et al., 1999). However, this time cannot be used unequivocally as a comparative parameter for developmental speed since $P$. pacificus undergoes one embryonic moult from $\mathrm{J} 1$ to $\mathrm{J} 2$ before hatching (Félix et al., 1999).

In $P$. pacificus, gastrulation started at $185 \mathrm{~min}$ in the 28 cell stage with the inward migration of the two intestinal precursors, Ea and Ep. As in C. elegans (28-cell stage after $100 \mathrm{~min}$ ), these precursor cells divided in the 44-cell stage after they had reached their final destination. The $\mathrm{P}_{4}$ cell always stayed in close proximity to the Ep cell and they moved inward, side-by-side, during gastrulation. This is in contrast to $C$. elegans where the daughters of $\mathrm{P}_{4}$ do so around the 100-cell stage.

Analyses were done on the division sequence, the cell cycle lengths and patterns, the spatial arrangement and the cleavage orientation of cells in different cell stages. All these parameters were found to vary within individuals.

\section{VARIABILITY IN DIVISION SEQUENCE}

The embryonic cell lineage of ten individuals at $20^{\circ} \mathrm{C}$ was reconstructed and the division sequences were compared up to at least the 50-cell stage (Table 1). From the 13-cell stage (eighth division) onwards, differences in the division sequence between individuals were found: a switch between MS and C was found in two out of ten individuals. From the 44-cell stage onwards, the sequences 

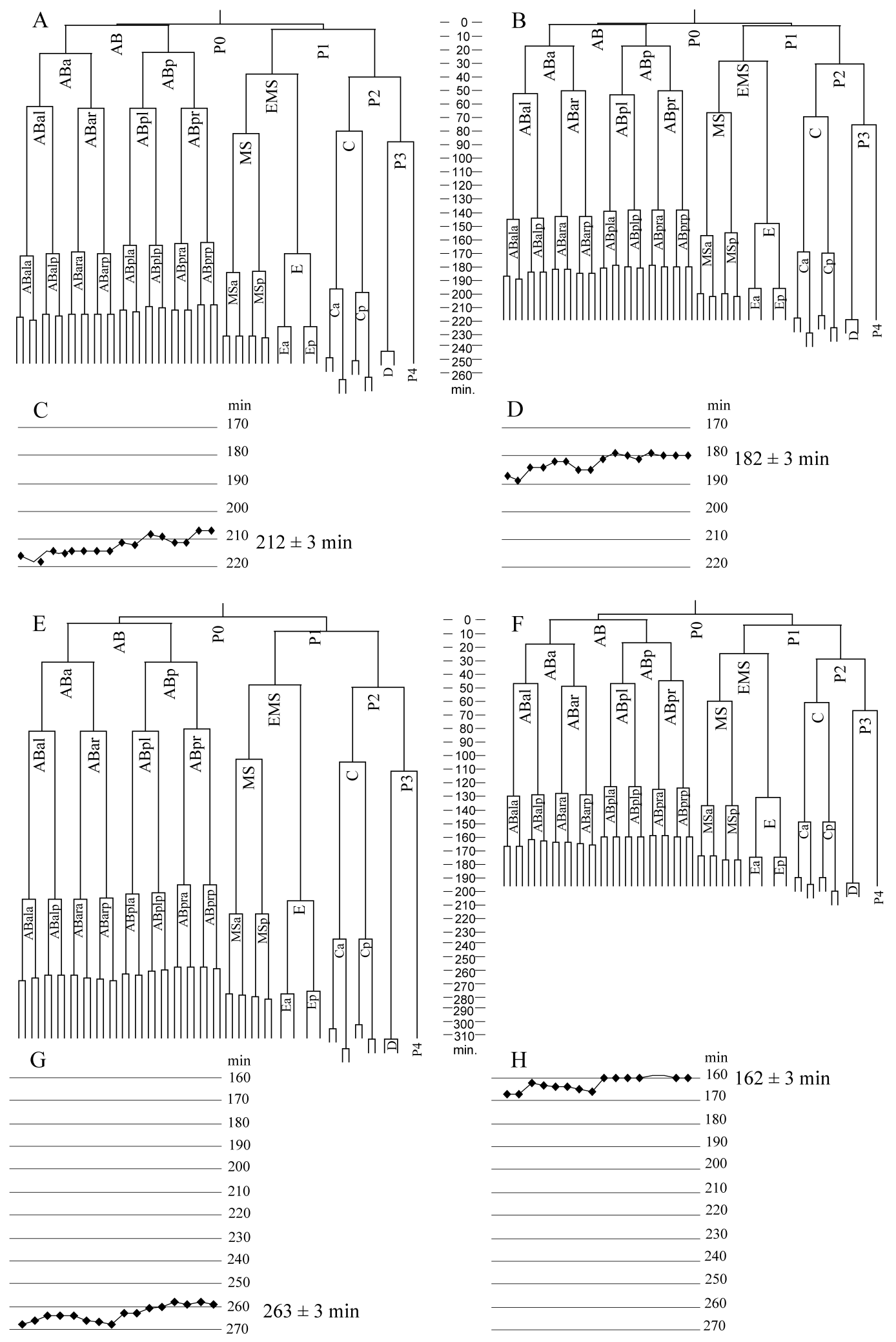
Table 1. Division sequence of early cleavages of Pristionchus pacificus in 12 embryos (embryos $1-10$ at $20^{\circ} \mathrm{C}$, embryo 11 at $15^{\circ} \mathrm{C}$, embryo 12 at $\left.25^{\circ} \mathrm{C}\right)$ and Caenorhabditis elegans $\left(20^{\circ} \mathrm{C}\right)$.

\begin{tabular}{|c|c|c|c|c|c|c|c|c|c|c|c|c|c|c|c|c|c|c|c|}
\hline \multirow[t]{2}{*}{ Embryo } & \multicolumn{19}{|c|}{ Division } \\
\hline & 1 & 2 & 3 & 4 & 5 & 6 & 7 & 8 & 9 & 10 & 11 & 12 & 13 & 14 & 15 & 16 & 17 & 18 & 19 \\
\hline Embryo 1 & P0 & $\mathrm{AB}$ & P1 & $2 \mathrm{AB}$ & EMS & $\mathrm{P} 2$ & $4 \mathrm{AB}$ & MS & $\mathrm{C}$ & P3 & $8 \mathrm{AB}$ & E & $2 \mathrm{MS}$ & $2 \mathrm{C}$ & $16 \mathrm{AB}$ & $2 \mathrm{E}$ & $4 \mathrm{MS}$ & $\mathrm{D}$ & $4 \mathrm{C}$ \\
\hline Embryo 2 & $\mathrm{P} 0$ & $\mathrm{AB}$ & P1 & $2 \mathrm{AB}$ & EMS & $\mathrm{P} 2$ & $4 \mathrm{AB}$ & $\mathrm{C}$ & MS & P3 & $8 \mathrm{AB}$ & E & $2 \mathrm{MS}$ & $2 \mathrm{C}$ & $16 \mathrm{AB}$ & $2 \mathrm{E}$ & $4 \mathrm{MS}$ & $4 \mathrm{C}$ & $32 \mathrm{AB}$ \\
\hline Embryo 3 & P0 & $\mathrm{AB}$ & P1 & $2 \mathrm{AB}$ & EMS & $\mathrm{P} 2$ & $4 \mathrm{AB}$ & MS & $\mathrm{C}$ & P3 & $8 \mathrm{AB}$ & E & $2 \mathrm{MS}$ & $2 \mathrm{C}$ & $16 \mathrm{AB}$ & $4 \mathrm{MS}$ & $2 \mathrm{E}$ & $\mathrm{D}$ & $4 \mathrm{C}$ \\
\hline Embryo 4 & $\mathrm{P} 0$ & $\mathrm{AB}$ & P1 & $2 \mathrm{AB}$ & EMS & $\mathrm{P} 2$ & $4 \mathrm{AB}$ & $\mathrm{C}$ & MS & P3 & $8 \mathrm{AB}$ & E & $2 \mathrm{MS}$ & $2 \mathrm{C}$ & $16 \mathrm{AB}$ & $2 \mathrm{E}$ & $4 \mathrm{MS}$ & $\mathrm{D}$ & $4 \mathrm{C}$ \\
\hline Embryo 5 & P0 & $\mathrm{AB}$ & $\mathrm{P} 1$ & $2 \mathrm{AB}$ & EMS & $\mathrm{P} 2$ & $4 \mathrm{AB}$ & MS & $\mathrm{C}$ & P3 & $8 \mathrm{AB}$ & E & $2 \mathrm{MS}$ & $2 \mathrm{C}$ & $16 \mathrm{AB}$ & $2 \mathrm{E}$ & $4 \mathrm{MS}$ & $4 \mathrm{C}$ & $32 \mathrm{AB}$ \\
\hline Embryo 6 & P0 & $\mathrm{AB}$ & P1 & $2 \mathrm{AB}$ & EMS & $\mathrm{P} 2$ & $4 \mathrm{AB}$ & MS & $\mathrm{C}$ & P3 & $8 \mathrm{AB}$ & E & $2 \mathrm{MS}$ & $2 \mathrm{C}$ & $16 \mathrm{AB}$ & $2 \mathrm{E}$ & $4 \mathrm{MS}$ & $\mathrm{D}$ & $4 \mathrm{C}$ \\
\hline Embryo 7 & P0 & $\mathrm{AB}$ & $\mathrm{P} 1$ & $2 \mathrm{AB}$ & EMS & $\mathrm{P} 2$ & $4 \mathrm{AB}$ & MS & $\mathrm{C}$ & P3 & $8 \mathrm{AB}$ & E & $2 \mathrm{MS}$ & $2 \mathrm{C}$ & $16 \mathrm{AB}$ & $2 \mathrm{E}$ & $\mathrm{D}$ & $4 \mathrm{MS}$ & $4 \mathrm{C}$ \\
\hline Embryo 8 & P0 & $\mathrm{AB}$ & $\mathrm{P} 1$ & $2 \mathrm{AB}$ & EMS & $\mathrm{P} 2$ & $4 \mathrm{AB}$ & MS & $\mathrm{C}$ & P3 & $8 \mathrm{AB}$ & E & $2 \mathrm{MS}$ & $2 \mathrm{C}$ & $16 \mathrm{AB}$ & $2 \mathrm{E}$ & $4 \mathrm{MS}$ & $\mathrm{D}$ & $4 \mathrm{C}$ \\
\hline Embryo 9 & $\mathrm{P} 0$ & $\mathrm{AB}$ & $\mathrm{P} 1$ & $2 \mathrm{AB}$ & EMS & $\mathrm{P} 2$ & $4 \mathrm{AB}$ & MS & $\mathrm{C}$ & P3 & $8 \mathrm{AB}$ & $\mathrm{E}$ & $2 \mathrm{MS}$ & $2 \mathrm{C}$ & $16 \mathrm{AB}$ & $2 \mathrm{E}$ & $4 \mathrm{MS}$ & $\mathrm{D}$ & $32 \mathrm{AB}$ \\
\hline Embryo 10 & P0 & $\mathrm{AB}$ & $\mathrm{P} 1$ & $2 \mathrm{AB}$ & EMS & $\mathrm{P} 2$ & $4 \mathrm{AB}$ & MS & $\mathrm{C}$ & P3 & $8 \mathrm{AB}$ & $\mathrm{E}$ & $2 \mathrm{MS}$ & $2 \mathrm{C}$ & $16 \mathrm{AB}$ & $2 \mathrm{E}$ & $4 \mathrm{MS}$ & $\mathrm{D}$ & $4 \mathrm{C}$ \\
\hline Embryo $11\left(15^{\circ} \mathrm{C}\right)$ & P0 & $\mathrm{AB}$ & $\mathrm{P} 1$ & $2 \mathrm{AB}$ & EMS & $\mathrm{P} 2$ & $4 \mathrm{AB}$ & MS & $\mathrm{C}$ & P3 & $8 \mathrm{AB}$ & $\mathrm{E}$ & $2 \mathrm{MS}$ & $2 \mathrm{C}$ & $16 \mathrm{AB}$ & $2 \mathrm{E}$ & $4 \mathrm{MS}$ & $\mathrm{D}$ & $4 \mathrm{C}$ \\
\hline Embryo $12\left(25^{\circ} \mathrm{C}\right)$ & $\mathrm{P} 0$ & $\mathrm{AB}$ & $\mathrm{P} 1$ & $2 \mathrm{AB}$ & EMS & $\mathrm{P} 2$ & $4 \mathrm{AB}$ & MS & $\mathrm{C}$ & P3 & $8 \mathrm{AB}$ & $\mathrm{E}$ & $2 \mathrm{MS}$ & $2 \mathrm{C}$ & $16 \mathrm{AB}$ & $2 \mathrm{E}$ & $4 \mathrm{MS}$ & $\mathrm{D}$ & $4 \mathrm{C}$ \\
\hline C. elegans & P0 & $\mathrm{AB}$ & $\mathrm{P} 1$ & $2 \mathrm{AB}$ & EMS & $\mathrm{P} 2$ & $4 \mathrm{AB}$ & MS & $\mathrm{E}$ & $\mathrm{C}$ & P3 & $8 \mathrm{AB}$ & $2 \mathrm{MS}$ & $2 \mathrm{C}$ & $16 \mathrm{AB}$ & $2 \mathrm{E}$ & $4 \mathrm{MS}$ & $4 \mathrm{C}$ & $32 \mathrm{AB}$ \\
\hline
\end{tabular}

showed a higher variation and switches between 4MS, 2E, $\mathrm{D}$ and $4 \mathrm{C}$ could be found. The lineages (Fig. 1) showed considerable variability in the timing of cell divisions in all founder cells and this increased with developmental time. The pattern of the $16 \mathrm{AB}$ cells was studied in detail and extracted below each lineage. In embryo 4, the divisions of the $16 \mathrm{AB}$ cells occurred on average at $212 \mathrm{~min}$ whilst in embryo 8 they occurred at $182 \mathrm{~min}$ (Fig. 1C, D).

\section{VARIABILITY IN CELL CYCLE LENGTHS AND PATTERN}

In embryo 4 and embryo 8 , the cell cycle of $8 \mathrm{AB}$ lasted $41 \mathrm{~min}$ and $49 \mathrm{~min}$, respectively (Fig. 1). The eight posterior $\mathrm{AB}$ cells divided on average 6 min (embryo 8) and 5 min (embryo 4) earlier than the anterior AB cells. This delay in division timing of the anterior cells was already visible when $8 \mathrm{AB}$ divided. Recordings made at other temperatures showed the same variability.

The mean cell cycle lengths in the $\mathrm{AB}$ lineage were compared for four cycles in all recordings. All recordings of $P$. pacificus showed the same pattern. This pattern was clearly different from the one seen in C. elegans where the mean cell cycle length increases slowly at an equal rate (Fig. 2). In P. pacificus, the mean cell cycle length extended and then became shorter with a peak in the $8 \mathrm{AB}$ generation. In recordings at $25^{\circ} \mathrm{C}$ there was an overall shorter mean cell cycle length in $\mathrm{AB}$ than in recordings at $20^{\circ} \mathrm{C}$ or $15^{\circ} \mathrm{C}$. The longest mean cell cycle length in $\mathrm{AB}$ was found at $15^{\circ} \mathrm{C}$ (unpubl.).

The length of division rounds, that is the time between the first and the last division of each division round, increased for the $\mathrm{AB}$ cells with developmental time (Fig. 3 ). At $25^{\circ} \mathrm{C}$ the length of the division rounds was shorter than the average length at $20^{\circ} \mathrm{C}$. However, a great deal of variation could be found at $20^{\circ} \mathrm{C}$. For instance, the $8 \mathrm{AB}$ cell stage divided in the fifth division round with periods ranging from 5 to $13 \mathrm{~min}$.

\section{VARIABILITY IN THE SPATIAL ARRANGEMENT OF BLASTOMERES}

Both poles of the embryo contained a remarkably large perivitelline space compared to $C$. elegans. As a consequence, the early blastomeres were very motile during early embryogenesis, leading to variable transient configurations in the early embryo. Therefore, we analysed cell contacts in different cell stages. Before the eight-cell stage, all embryos had the same topology. In the eight-

Fig. 1. Variability of cell division timing in the AB lineage. The figure shows the lineages of embryo $4(A)$ and embryo $8(B)$ at $20^{\circ} C$, embryo 11 at $15^{\circ} \mathrm{C}(\mathrm{E})$ and embryo 12 at $25^{\circ} \mathrm{C}(\mathrm{F})$. The vertical axis indicates time of development and every division is visualised by a horizontal bar. The anterior sister is always to the left. The pattern of the $16 \mathrm{AB}$ cells is extracted below each lineage $(C=e m b r y o$, $D=$ embryo 8, $G=$ embryo 11 and $H=$ embryo 12). The mean time of the cell divisions is indicated. 


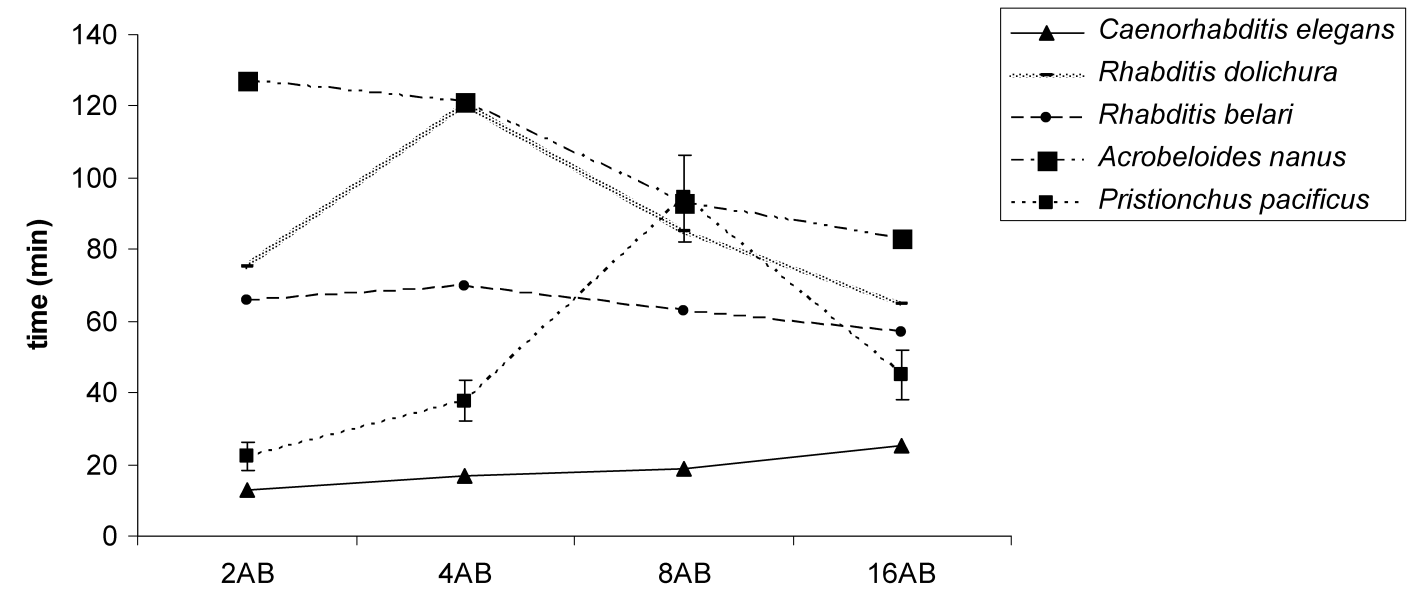

Fig. 2. Mean cell cycle lengths of $A B$ generations plotted over time for Caenorhabditis elegans, Rhabditis dolichura, R. belari, Acrobeloides nanus (data from Laugsch and Schierenberg, 2004) and Pristionchus pacificus (12 individuals).

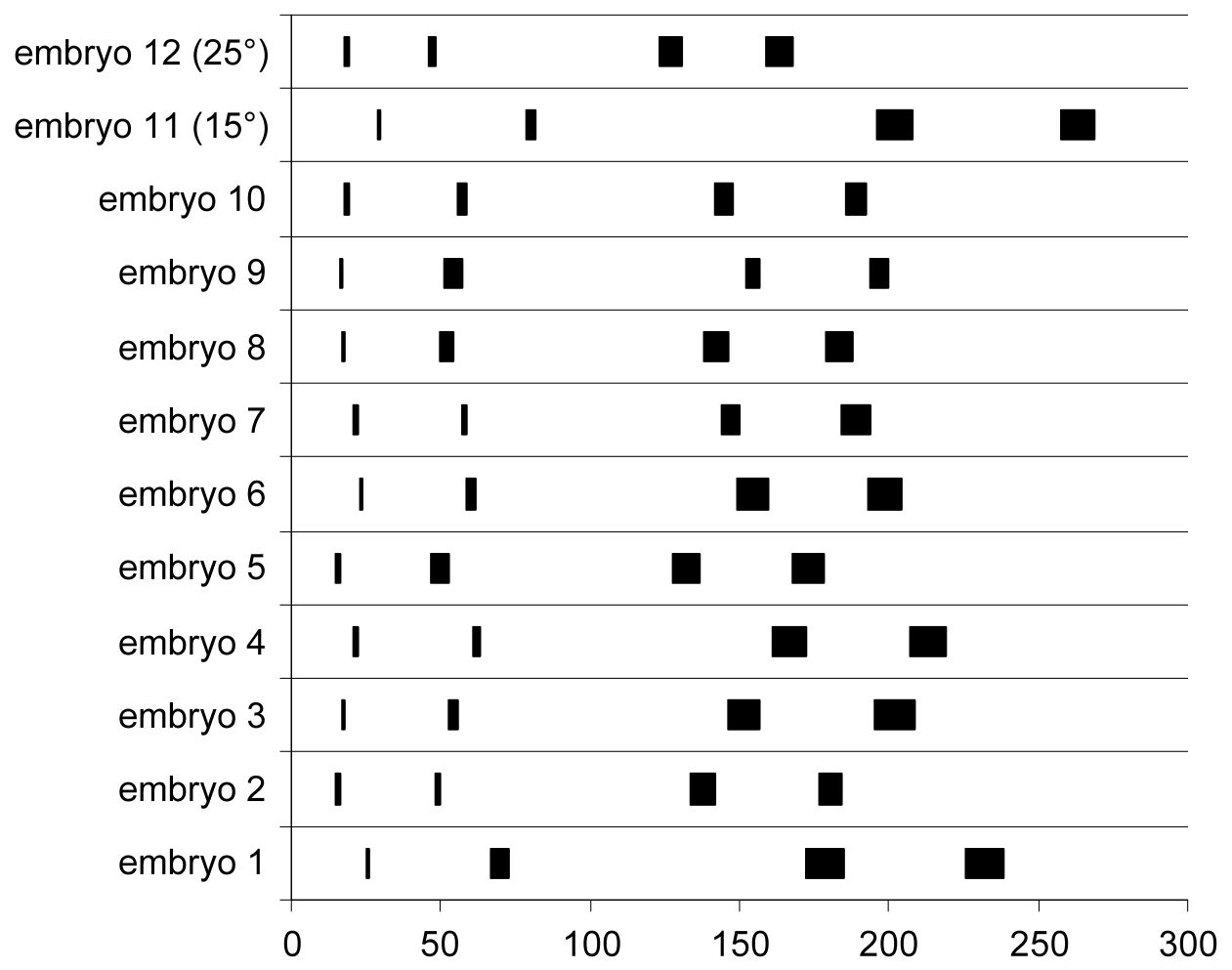

Fig. 3. Cell division periods of generations of $A B$ cells (until the 16AB stage) in Pristionchus pacificus. Each box indicates the time from the division of the first cell to the division of the last cell. Time (min) starts after the division of AB. 


\begin{tabular}{|c|c|c|c|c|c|c|c|c|c|c|c|c|}
\hline & ala & alp & ara & $\operatorname{arp}$ & pla & plp & pra & prp & MS & $E$ & C & P3 \\
\hline \multirow{2}{*}{ ala } & & 1 & 1 & 1 & 1 & 0 & 0 & 0 & 0 & 0 & 0 & 0 \\
\hline & & 1 & 1 & 0 & 1 & $5 / 13$ & 0 & 0 & 0 & & & \\
\hline \multirow{2}{*}{ alp } & & & 1 & 0 & $9 / 12$ & 1 & 0 & 0 & 1 & 0 & 0 & 0 \\
\hline & & & 1 & 0 & $8 / 13$ & 1 & 0 & 0 & 1 & & & \\
\hline \multirow{2}{*}{ ara } & & & & 1 & 1 & $5 / 12$ & 1 & 1 & 1 & 0 & 0 & 0 \\
\hline & & & & 1 & 1 & $8 / 13$ & 1 & $7 / 13$ & 1 & & & \\
\hline \multirow{2}{*}{ arp } & & & & & 1 & $7 / 12$ & 1 & $4 / 12$ & 0 & 0 & 1 & 0 \\
\hline & & & & & 1 & 1 & 1 & $5 / 13$ & 0 & & & \\
\hline \multirow{2}{*}{ pla } & & & & & & 1 & 0 & 1 & $3 / 12$ & 0 & 1 & 0 \\
\hline & & & & & & 1 & 0 & 0 & 0 & & & \\
\hline \multirow{2}{*}{ plp } & & & & & & & 0 & $4 / 12$ & 1 & 1 & 1 & 0 \\
\hline & & & & & & & 0 & 0 & 1 & & & \\
\hline \multirow{2}{*}{ pra } & & & & & & & & 1 & 0 & $3 / 12$ & 1 & 0 \\
\hline & & & & & & & & 1 & $6 / 13$ & & & \\
\hline prp & & & & & & & & & 1 & 1 & 1 & 0 \\
\hline \multirow{2}{*}{ MS } & & & & & & & & & & 1 & 0 & 0 \\
\hline & & & & & & & & & & I & $\sigma$ & 6 \\
\hline$E$ & & & & & & & & & & & 1 & 1 \\
\hline C & & & & & & & & & & & & 1 \\
\hline P3 & & & & & & & & & & & & \\
\hline
\end{tabular}

Fig. 4. Cell-cell contacts at the 12-cell stage in Pristionchus pacificus (upper line) and Caenorhabditis elegans (lower line) $(1=$ contact is present, $0=$ contact is absent). Variable contacts are marked by a grey square. (C. elegans data from Hutter and Schnabel, 1994, 1995a.)

cell stage the contacts between $\mathrm{P}_{3}$ and the posterior granddaughter cells of $\mathrm{AB}$ were variable: in four of 12 embryos $\mathrm{P}_{3}$ contacted $\mathrm{ABpl}$, whilst in seven of 12 embryos $\mathrm{P}_{3}$ contacted $\mathrm{ABpr}$. In one embryo, $\mathrm{P}_{3}$ contacted both $\mathrm{ABpl}$ and ABpr. In addition, ABar contacted $\mathrm{C}$ in four of $12 \mathrm{em}-$ bryos. In the 12-cell stage, more variable configurations could be seen (Fig. 4). There was a problem in appointing the anterior daughter cell of $\mathrm{ABal}$, since in six out of 12 recordings the anterior daughter cell was located dorsally from the posterior daughter, whilst in three out of 12 recordings it was found ventrally from the posterior daughter. In three out of 12 recordings, ABal divided strictly dorsoventrally. Thus, analogous to the C. elegans lineage, the dorsal cell was appointed as the ABala cell for all recordings, regardless of whether it was the most anterior cell.

Fifty-nine out of 66 possible cell-cell contacts in the 12-cell stage ( $8 \mathrm{AB}$ cell stage) were found to be invariant in all 12 embryos (Fig. 4). Seven cell-cell contacts were found to be variable (indicated by a grey square) and three of these variable contacts were also variable in $C$. elegans. Within the $\mathrm{AB}$ lineage, two contacts were found to be different in C. elegans (in all recordings): the contacts $\mathrm{ABala}-\mathrm{AB}$ arp and $\mathrm{ABpla}-\mathrm{ABprp}$ were present in P. pacificus, but not in C. elegans (Fig. 5). As in C. elegans, cell-cell contacts between $\mathrm{AB}$ and $\mathrm{P}_{1}$ descendants also showed variability, contacts ABpla-MS and ABpra-E being found in three of 12 embryos.

Other important cell-cell contacts in the 24- and 26-cell stage of $C$. elegans embryogenesis that are essential for induction have been described by Hutter and Schnabel (1995a). These contacts (ABalap-ABplaa and ABplpaMSap) were analysed in $P$. pacificus and found to be present.

\section{VARIABILITY IN CLEAVAGE ORIENTATION}

The cleavage orientation of all $\mathrm{AB}$ cells up to the $16 \mathrm{AB}$-cell stages was analysed. As in C. elegans, the AB 

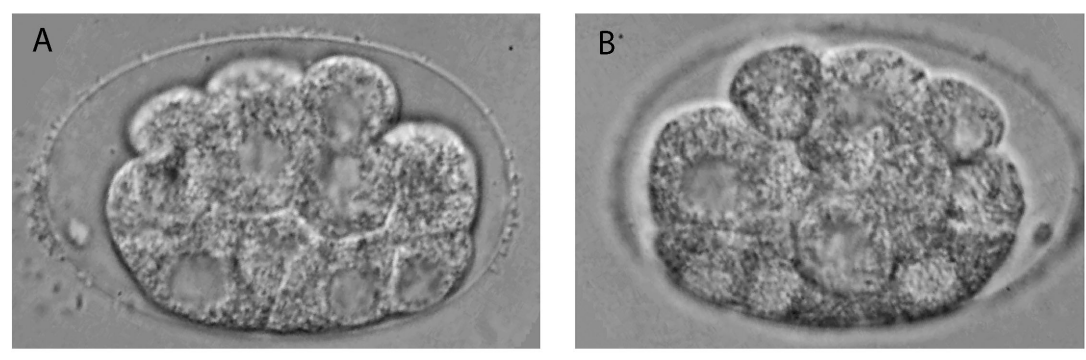

$\mathrm{D}$

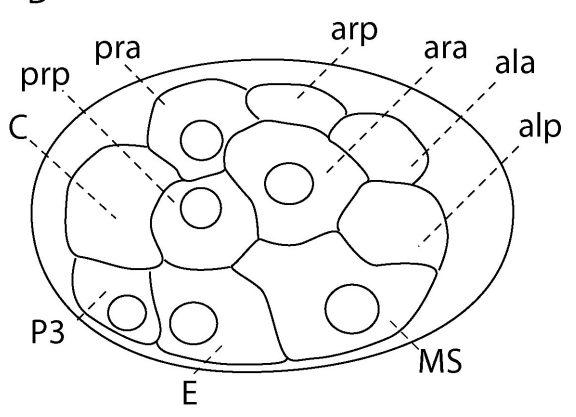

$\mathrm{E}$

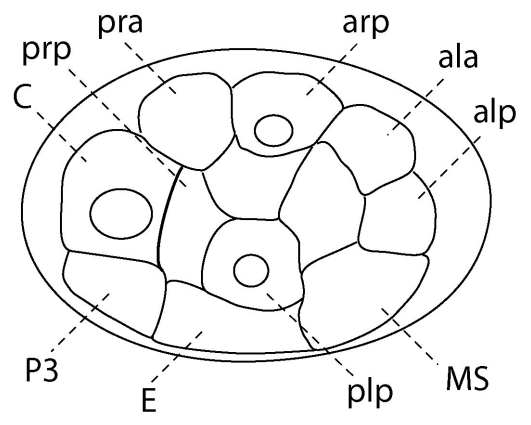

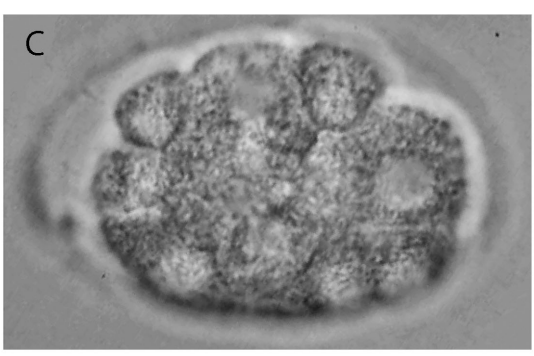

$\mathrm{F}$

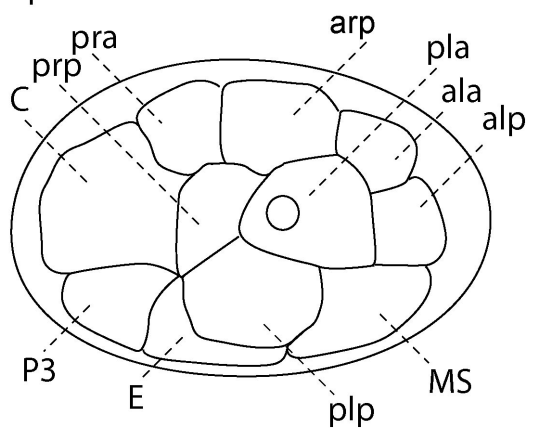

Fig. 5. Cell-cell contacts in a 12-cell embryo. Right ventral view, anterior to the right. (A-C) Nomarski pictures of an upper (A), medial $(B)$ and lower $(C)$ focal plane of embryo 2. (D-F) Drawings corresponding to the pictures $(A-C)$. For clarity the $A B$ prefix in the $A B$ cells was omitted. The contacts ABala-ABarp, ABpla-ABprp exist in Pristionchus pacificus, but not in Caenorhabditis elegans. The cells are named according to Sulston et al. (1983).

blastomere in $P$. pacificus divided along the dorsoventral axis and the following divisions of the two $\mathrm{AB}$ daughter cells were along the left-right axis. All AB granddaughter cells in P. pacificus divided nearly dorsoventrally (mean division angle of $83 \pm 7^{\circ}$ ), with the exception of $\mathrm{ABpl}$ (Table 2; Fig. 5). This is in contrast to C. elegans where the division axes of the third cleavage of the descendants of the anterior blastomere $\mathrm{AB}$ occur along the anteroposterior axis, with the exception of ABar (Hutter \& Schnabel, 1995a). In the 8AB-cell stage in P. pacificus cells divided mainly along the a-p axis (mean division angle is $28 \pm 18^{\circ}$ ), with the exception of $\mathrm{ABalp}$, which division had a more dorsoventral orientation $\left(65 \pm 12^{\circ}\right)$.

\section{Discussion}

\section{GENERAL FEATURES OF EARLY DEVELOPMENT: OVERALL DIFFERENCES AND SIMILARITIES WITH C. ELEGANS}

In general we found that the development of P. pacificus was similar to that of $C$. elegans. Pristionchus pacificus developed at a speed that is relatively fast compared to other nematodes and typical for opportunists, which are able to reproduce very fast under favourable conditions. In contrast to $C$. elegans, which preferentially lives in decomposing habitats such as compost heaps, $P$. pacificus most likely has a necromenic association with the beetle (Zauner et al., 2007). A fast development, an obvious advantage in a rapidly decomposing arthropod, is also reflected in the late establishment of $\mathrm{P}_{4}$ (15-cell stage). It is known that in a slow developing nematode, such as Acrobeloides nanus, which develops five times slower than $C$. elegans, the germline separates relatively earlier (six-cell stage) (Skiba \& Schierenberg, 1992). It is assumed that the early separation of the germline from the somatic cells is a necessary process to preserve germline quality (Skiba \& Schierenberg, 1992).

\section{CELl CyClE CONTROL AND MATERNAL SUPPLY}

The peak in the mean cell cycle length of the $A B$ generations in $P$. pacificus has also been observed in Rhabditis dolichura (Laugsch \& Schierenberg, 2004). They showed that variations in cell cycle rhythms in different nematode species may be caused by a differential maternal contribution. In this case, a delay in cell cycle 
Table 2. Cleavage orientation of AB cells in Pristionchus pacificus: division angles expressed as deviation from the a-p axis in degrees. The mean division angle and standard deviation of each $A B$ cell is below each column.

\begin{tabular}{|c|c|c|c|c|c|c|c|c|c|c|c|c|}
\hline & \multicolumn{4}{|c|}{ Division 4AB-8AB } & \multicolumn{8}{|c|}{ Division $8 \mathrm{AB}-16 \mathrm{AB}$} \\
\hline & ABal & ABar & $\mathrm{ABpl}$ & $\mathrm{ABpr}$ & ABala & ABalp & ABara & ABarp & ABpla & ABplp & ABpra & ABprp \\
\hline Embryo 1 & 86 & 84 & 73 & 89 & 31 & 69 & 16 & 17 & 14 & 32 & 0 & 4 \\
\hline Embryo 2 & 87 & 88 & 69 & 85 & 56 & 71 & 36 & 10 & 23 & 37 & 36 & 16 \\
\hline Embryo 3 & 78 & 89 & 65 & 80 & 59 & 69 & 49 & 12 & 10 & 21 & 32 & 43 \\
\hline Embryo 4 & 83 & 88 & 28 & 69 & 23 & 50 & 17 & 6 & 37 & 34 & 24 & 60 \\
\hline Embryo 5 & 89 & 87 & 43 & 83 & 54 & 71 & 21 & 3 & 4 & 45 & 19 & 53 \\
\hline Embryo 6 & 88 & 83 & 68 & 86 & 50 & 71 & 68 & 2 & 19 & 49 & 4 & 42 \\
\hline Embryo 7 & 85 & 80 & 70 & 84 & 33 & 63 & 50 & 1 & 2 & 25 & 10 & 3 \\
\hline Embryo 8 & 82 & 88 & 33 & 88 & 37 & 38 & 11 & 11 & 31 & 63 & 30 & 49 \\
\hline Embryo 9 & 72 & 78 & 47 & 56 & 48 & 55 & 44 & 13 & 28 & 41 & 33 & 49 \\
\hline Embryo 10 & 79 & 84 & 61 & 80 & 41 & 70 & 35 & 10 & 1 & 25 & 10 & 23 \\
\hline Embryo $11\left(15^{\circ}\right)$ & 88 & 87 & 80 & 83 & 46 & 81 & 42 & 1 & 6 & 50 & 20 & 15 \\
\hline Embryo $12\left(25^{\circ}\right)$ & 82 & 87 & 44 & 81 & 54 & 74 & 51 & 15 & 21 & 46 & 10 & 14 \\
\hline Mean & 83 & 85 & 57 & 80 & 44 & 65 & 37 & 8 & 16 & 39 & 19 & 31 \\
\hline SD & 5 & 3 & 17 & 9 & 11 & 12 & 17 & 6 & 12 & 12 & 12 & 20 \\
\hline
\end{tabular}

rhythms could indicate a time gap between the depletion of the maternal gene products and the availability of zygotic gene products. In $P$. pacificus the peak occurred one cell cycle later, suggesting that the contribution of maternal gene products was larger in our species. In $P$. pacificus there was an absence of cleavage for $1 \mathrm{~h}$ after the division of $\mathrm{P}_{3}$, whilst in $R$. dolichura this phase lasts longer (at $25^{\circ} \mathrm{C}$ ) and is observed prior to the division of $\mathrm{P}_{3}$. This differential supply of maternal gene products strongly influences the speed of early development. In C. elegans, where cell cycles of 12-20 min are found, early embryogenesis is heavily dependent on gene products synthesised during oogenesis (Edgar et al., 1994; Bowerman, 1998). This is in contrast to A. nanus, which has longer cell cycles decreasing in time, because less maternal material is present and newly zygotic gene products only become available over time (Wiegner \& Schierenberg, 1999).

\section{VARIABILITY IN TIMING OF CELL DIVISIONS}

A comparison of the cleavage sequence of 12 individuals of $P$. pacificus (Table 1) revealed how variable early development can be: from the 13-cell stage onward, differences in division sequence were found and these became more pronounced in later divisions. In addition, the lengths of the division rounds seemed to be variable and this variability increased with developmental time. Sul- ston et al. (1983) previously mentioned a variation in the timing of cell divisions (10\%) during the early embryogenesis of $C$. elegans, but their lineage was based on different embryos. Using the 4D system, the natural variability of cleavage was studied in $C$. elegans by Schnabel et al. (1997). They showed that in C. elegans the timing of individual cleavages can vary in the mid-embryonic phase. Analysis of the timing of cell cleavages and the occurrence of programmed cell death in the ABala lineage revealed a significant variability (Schnabel et al., 1997). They suggested that cells that acquire variable positions during embryogenesis - partly due to the variability of cleavage timing - are later tied together by a sorting process, a new mechanism of pattern formation, which they called "cell focusing" (Bischoff \& Schnabel, 2006b; Schnabel et al., 2006).

\section{DO THE SAME INDUCTIONS OCCUR IN P. PACIFICUS?}

Variations in the cell division timing of early embryogenesis may result in an altered spatial arrangement of blastomeres. In the 12-cell stage, seven contacts were found to be variable and these results are in agreement with those of Hutter and Schnabel (1995a). However, this variability appears to be low enough so that crucial cell-cell contacts, relevant for cell fate specifications through inductions, are maintained. For instance, in the 4-cell embryo, there is an induction from $\mathrm{P}_{2}$ to the EMS cell to ensure proper estab- 
lishment of the gut founder cell E (Goldstein, 1992). Two successive inductions necessary to induce pharyngeal development in the $C$. elegans embryo have been described by Hutter and Schnabel (1994). These two cell-cell contacts, ABalp-MS and ABara-MS, are found in P. pacificus. Another important induction establishes left-right asymmetry in the $\mathrm{ABpla} / \mathrm{pra}$ lineage and requires cell-cell contact between the ABalap and ABplaa blastomeres in the 24-cell stage of the C. elegans embryo (Hutter \& Schnabel, 1995b). Lastly, a final induction in C. elegans by MSap concerns the development of the left-right asymmetry in the ABplp/ABprp lineage and requires contact between ABplpa and MSap in the 26-cell stage (Hutter \& Schnabel, 1995b). Both cell-cell contacts were present in the P. pacificus embryo so an analogue mechanism to specify the different fates of the $\mathrm{AB}$ descendants is feasible. However, study of these inductions on a molecular level, in addition to cell ablation experiments, should provide more insight into this process.

\section{THE THIRD CLEAVAGE OF AB IN $P$. PACIFICUS IS DIFFERENT FROM THAT OF $C$. ELEGANS}

Despite similar cell-cell contacts, analysis of the division axes of all $\mathrm{AB}$ cells until the 16AB-cell stage revealed a potential blastomere specification difference with C. elegans. While in C. elegans the third division of the $\mathrm{AB}$ lineage occurs along the anterior-posterior axis (with the exception of $\mathrm{ABar}$ ), in P. pacificus a much more dorsoventral orientation of the division axes was found. The importance of the precise orientation of cell division axes in embryos for partitioning segregated cytoplasmic components to particular daughter cells was illustrated by Hutter and Schnabel (1995a), who suggested a model whereby an induction from $\mathrm{P}_{1}$ to $\mathrm{AB}$ in the two-cell stage is necessary to specify the fates of the four posterior $A B$ cells in the 12-cell stage. It is essential that the third cleavage occurs along the antero-posterior axis so that a polarisation between posterior and anterior cell is possible. When cells divide along the dorsoventral axis, the establishment of a graded cytoplasmic content is not possible, suggesting an alternative mechanism to specify $\mathrm{AB}$ derived blastomeres in P. pacificus.

Walston et al. (2004) studied the division orientation of ABar in C. elegans in detail and showed that the spindle orientation, which is perpendicular to the other three $\mathrm{AB}$ granddaughters, depends on contact with the C blastomere. In P. pacificus, contact between ABar and $\mathrm{C}$ was seen in only four of the 12 embryos prior to the division of ABar, so the contribution of this pathways to the polarisation of ABar remains unclear. It is possible that another mechanism, independent of contact with the $\mathrm{C}$ blastomere, is operational. Bischoff and Schnabel (2006a) postulated that in the C. elegans embryo $\mathrm{P}_{2}$ and its descendants constitute a polarising centre in the posterior of the embryo which orientates the cell cleavages of AB-derived blastomeres along the a-p axis. However, in P. pacificus the third cleavage of the $\mathrm{AB}$ descendants occurred along the dorsoventral axis and an active polarising centre seems not to be involved. In the next division round, divisions of $\mathrm{AB}$ blastomeres mainly occurred along the a-p axis, hence, the relay mechanism was possibly delayed for one division round.

\section{Acknowledgements}

We thank K. Matheve and L. Verhoeven for help with the calculation of the division angles. This work benefited from the suggestions and critical reviews of T. Tytgat and M. Willems and two anonymous reviewers. This work was supported by funding from G.0033.06N to G.B. Some nematode strains used in this work were provided by the Caenorhabditis Genetics Center, which is funded by the NIH National Center for Research Resources (NCRR).

\section{References}

BISChoff, M. \& SchnABEL, R. (2006a). A posterior centre establishes and maintains polarity of the Caenorhabditis elegans embryo by a Wnt-dependent relay mechanism. Public Library of Science Biology 4, e396.

BISCHOFF, M. \& SCHNABEL, R. (2006b). Global cell sorting is mediated by local cell-cell interactions in the C. elegans embryo. Developmental Biology 294, 432-444.

BOWERMAN, B. (1998). Maternal control of pattern formation in early Caenorhabditis elegans embryos. Current Topics in Developmental Biology 39, 73-117.

BRENNER, S. (1974). The genetics of Caenorhabditis elegans. Genetics 77, 71-94.

Dolinski, C., Baldwin, J.G. \& Thomas, W.K. (2001). Comparative survey of early embryogenesis of Secernentea (Nematoda), with phylogenetic implications. Canadian Journal of Zoology 79, 82-94.

EdGaR, L.G., Wolf, N. \& Wood, W.B. (1994). Early transcription in Caenorhabditis elegans. Development 120, 443-451.

Eizinger, A., Jungblut, B. \& Sommer, R.J. (1999). Evolutionary change in the functional specificity of genes. Trends in Genetics 15, 197-202. 
FÉliX, M.A., Hill, R.J., Schwarz, H., SternberG, P.W., Sudhaus, W. \& SOMMER, R.J. (1999). Pristionchus pacificus, a nematode with only three juvenile stages, displays major heterochronic changes relative to Caenorhabditis elegans. Proceedings of the Royal Society B: Biological Sciences 266, 1617-1621.

Goldstein, B. (1992). Induction of gut in Caenorhabditis elegans embryos. Nature 357, 255-257.

Goldstein, B., Frisse, L.M. \& Thomas, W.K. (1998). Embryonic axis specification in nematodes: evolution of the first step in development. Current Biology 8, 157-160.

Hasegawa, K., Futai, K., Miwa, S. \& Miwa, J. (2004). Early embryogenesis of the pinewood nematode Bursaphelenchus xylophilus. Development, Growth and Differentiation 46, 153-161.

Herrmann, M., Mayer, W.E. \& Sommer, R.J. (2006). Nematodes of the genus Pristionchus are closely associated with scarab beetles and the Colorado potato beetle in Western Europe. Zoology 109, 96-108.

HiRd, S. \& WhiTE, J.G. (1993). Cortical and cytoplasmic flow polarity in early embryonic cells of Caenorhabditis elegans. Journal of Cell Biology 121, 1343-1355.

Holterman, M., van Der WurfF, A., van den Elsen, S., van Megen, H., Bongers, T., Holovachov, O., BAKKeR, J. \& Helder, J. (2006). Phylum-wide analysis of SSU rDNA reveals deep phylogenetic relationships among nematodes and accelerated evolution toward crown clades. Molecular Biology and Evolution 23, 1792-1800.

Hong, R.L. \& SOMmer, R.J. (2006). Pristionchus pacificus: a well-rounded nematode. BioEssays 28, 651-659.

Houthoofd, W. \& Borgonie, G. (2007). The embryonic cell lineage of the nematode Halicephalobus gingivalis (Nematoda: Cephalobina: Panagrolaimoidea). Nematology 9, 573-584.

Houthoofd, W., Jacobsen, K., Mertens, C., VangesTel, S., Coomans, A. \& Borgonie, G. (2003). Embryonic cell lineage of the marine nematode Pellioditis marina. Developmental Biology 258, 57-69.

Houthoofd, W., Willems, M., Jacobsen, K., Coomans, A. \& Borgonie, G. (2007). The embryonic lineage of the nematode Rhabditophanes sp. International Journal of Developmental Biology, in press.

Hutter, H. \& Schnabel, R. (1994). glp-1 and inductions establishing embryonic axes in C. elegans. Development 120 , 2051-2064.

Hutter, H. \& Schnabel, R. (1995a). Specification of anterior-posterior differences within the $\mathrm{AB}$ lineage in the C. elegans embryo: a polarising induction. Development 121 , 1559-1568.

Hutter, H. \& Schnabel, R. (1995b). Establishment of left-right asymmetry in the Caenorhabditis elegans embryo: a multistep process involving a series of inductive events. Development 121, 3417-3424.
Lahl, V., Halama, C. \& Schierenberg, E. (2003). Comparative and experimental embryogenesis of Plectidae (Nematoda). Development Genes and Evolution 213, 18-27.

Lahl, V., SAdler, B. \& SchierenberG, E. (2006). Egg development in parthenogenetic nematodes: variations in meiosis and axis formation. International Journal of Developmental Biology 50, 393-398.

LAugsch, M. \& Schierenberg, E. (2004). Differences in maternal supply and early development of closely related nematode species. International Journal of Developmental Biology 48, 655-662.

MalakHov, V.V. (1994). Nematodes. Structure, development, classification and phylogeny. Hope, W.D. (Ed.). Washington and London, Smithsonian Institution Press, $286 \mathrm{pp}$.

Mayer, E.M., Herrmann, M. \& Sommer, R.J. (2007). Phylogeny of the nematode genus Pristionchus and implications for biodiversity, biogeography and the evolution of hermaphroditism. BMC Evolutionary Biology 7, 104. doi: 10.1186/1471-2148-7-104.

Pires-DaSilva, A. \& Sommer, R. (2004). Conservation of the global sex determination gene tra- 1 in distantly related nematodes. Genes and Development 18, 1198-1208.

Rudel, D., Riebesell, M. \& Sommer, R.J. (2005). Gonadogenesis in Pristionchus pacificus and organ evolution: development, adult morphology and cell/cell interactions in the hermaphrodite gonad. Developmental Biology 277, 200221.

SCHIERENBERG, E. (2005). Unusual cleavage and gastrulation in a freshwater nematode: developmental and phylogenetic implications. Development Genes and Evolution 215, 103108.

Schnabel, R., Hutter, H., Moerman, D. \& Schnabel, H. (1997). Assessing normal embryogenesis in Caenorhabditis elegans using a 4D microscope: variability of development and regional specification. Developmental Biology 184, 234265.

Schnabel, R., Bischoff, M., Hintze, A., Schulz, A.K., Hejnol, A., Meinhardt, H. \& Hutter, H. (2006). Global cell sorting in the $C$. elegans embryo defines a new mechanism for pattern formation. Developmental Biology 294, 418-431.

Sigrist, C.B. \& Sommer, R.J. (1999). Vulva formation in Pristionchus pacificus relies on continuous gonadal induction. Development Genes and Evolution 209, 451-459.

SkibA, F. \& SchierenberG, E. (1992). Cell lineages, developmental timing and spatial pattern formation in embryos of free-living soil nematodes. Developmental Biology 151, 597610.

Sommer, R.J. (2000). Evolution of nematode development. Current Opinion in Genetics and Development 10, 443-448.

Sommer, R.J. (2001). As good as they get: cells in nematode vulva development and evolution. Current Opinions in Cell Biology 13, 715-720. 
SOMmER, R.J. (2005). Evolution of development in nematodes related to $C$. elegans (December 14, 2005), WormBook. The C. elegans Research Community, WormBook, available online at http://www.wormbook.org, doi/ 10.1895/wormbook.1.46.1.

Sommer, R.J. \& SternberG, P.W. (1994). Changes of induction and competence during the evolution of vulva development in nematodes. Science 5168, 114-118.

Sommer, R.J. \& SternberG, P.W. (1996). Evolution of nematode vulval fate patterning. Developmental Biology 17, 396-407.

Sommer, R.J., CARTA, L.K., Kim, S.-Y. \& SternberG, P.W. (1996). Morphological, genetic and molecular description of Pristionchus pacificus sp. n. (Nematoda: Neodiplogastridae). Fundamental and Applied Nematology 19, 511521.

SPIELER, M. \& SCHIERENBERG, E. (1995). On the development of the alternating free-living and parasitic generations of the nematode Rhabdias bufonis. Invertebrate Reproduction and Development 28, 193-203.

Srinivasan, J., Sinz, W., Lanz, C., Brand, A., NANDakumar, R., Raddatz, G., Witte, H., Keller, H., Kipping, I., Pires-daSilva, A., Jesse, T., Millare, J., De Both, M., Schuster, S.C. \& Sommer, R.J. (2002). A BAC-based genetic linkage map of the nematode Pristionchus pacificus. Genetics 162, 129-134.
Srinivasan, J., SinZ, W., Jesse, T., WiggersPerebolte, L., Jansen, K., Buntjer, J., VAN DeR Meulen, M. \& Sommer, R.J. (2003). An integrated physical and genetic map of the nematode Pristionchus pacificus. Molecular Genetics and Genomics 269, 715-722.

Sulston, J.E., Schierenberg, E., White, J.G. \& ThomSON, J.N. (1983). The embryonic cell lineage of the nematode C. elegans. Developmental Biology 100, 64-119.

Voronov, D.A. \& PANChin, Y.V. (1998). Cell lineage in the marine nematode Enoplus brevis. Development 125, 143-150.

Walston, T., Tuskey, C., Edgar, L., Hawkins, N., Ellis, G., Bowerman, B., WoOd, W. \& Hardin, J. (2004). Multiple Wnt signaling pathways converge to orient the mitotic spindle in early $C$. elegans embryos. Developmental Cell 7, 831-841.

WiEgner, O. \& SCHIERENBERG, E. (1999). Regulative development in a nematode embryo: a hierarchy of cell fate transformations. Developmental Biology 215, 1-12.

Zauner, H., Mayer, W.E., Herrmann, M., Weller, A., ERWIG, M. \& SOMMER, R.J. (2007). Distinct patterns of genetic variation in Pristionchus pacificus and Caenorhabditis elegans, two partially selfing nematodes with cosmopolitan distribution. Molecular Ecology 16, 1267-1280. 